\title{
Chinese-characterized Terms Translation on the Functional Equivalence Theory
}

\author{
Xuedong Shi \\ Foreign Language Department, Beijing Information Science \& Technology University, Beijing, China
}

\begin{abstract}
Since the reform and opening-up policy, the whole world has witnessed China's setting-off. In addition to the economic boom, China also lays stress on strengthening her culture soft power in the outside world. Hence, an increasing number of words with Chinese characteristics have appeared. In regard to the translation of these Chinese-characterized words, lots of translators and scholars have put forward different translating methods. From the perspective of functional equivalence theory, in most cases, due to the differences of cultural background and linguistic customs between Chinese and English, it is impossible to reach total equivalence in form and meaning. On this occasion, the translator can choose a suitable approach to reach the functional equivalence. Through analyzing the translation of Chinese-characterized terms, the author tries to explain these useful methods from the perspective of functional equivalence.
\end{abstract}

Index Terms - Chinese-characterized terms, functional equivalence, translation

\section{INTRODUCTION}

With the economic and social development in recent years, China has attracted the world's attention. Also, Chinese people have realized the significance of improving a good image in the world through international exchanges. In the interaction with the outside world, many Chinese-characterized terms have emerged, especially in the governmental documents, news reports, leaders' speeches, etc. These terms, with vivid images, originate from the Chinese culture, having the concise and strong culture characteristics, but we can seldom find the equivalents in English, which makes it a hard nut to crack for translators.

In order to reach suitable translations, many translators and scholars have made great efforts in their researches, but few of them have tried to view the translation from the point of the equivalent principle. Thus the author of this paper tries to explain the rendering of the Chinese-characterized words and phrases from the principle.

\section{LITERATURE REVIEW}

The term "equivalence" may refer to different concepts in different disciplines ranging from mathematics, logic, chemistry, computing to ethics, law, economy and art. In translation studies, equivalence is always a central issue which has caused heated controversy among many scholars. Equivalence is a basic and core concept existing since the beginning of translation and attracting the attention of all the translators and theorists. Equivalence can be considered as the relationship between the source text (ST) and the target text (TT), which is what translation activities seek for. The ideal translation should find complete equivalent in target-language (TL) to source-language (SL) in both content and form. (Nida, 2004) However, this ideal can hardly be achieved in reality because of numerous factors working upon translation such as great differences between two languages and cultures and the subjectivity of the source authors, the translators and the readers of target text. As Susan Bassnett puts it, equivalence in translation cannot be sought for as sameness, because even in the different versions in the same language sameness does not exist, let alone the translation. (Bassnett, 2002/2004). Studies on equivalence have been on the progress with the advance of translation studies in the West. In the early stage, scholars often explain and identify translation problems from a linguistic perspective. When it comes to text-linguistic approaches, equivalence is applied to smaller units of the text such as phonemes, morphemes and phrases. Later, some scholars started to deal with translation studies using functional-based and communicative approaches. In the later stage, people began to realize that translation cannot be only defined as SL to TL language transfer. The contexts within which translation happens should also be considered. Thus the translation study begins to turn to culture from under the umbrella of linguistics. So the translation equivalence is under heated discussion historically, socially and culturally. (Nida, 2004)

We can name a number of innovative theorists on the equivalence such as Jacobson, Nida, House, Catford, Wilss, Koller, Popovic, Bassett, Baker, etc.

Roman Jakobson, the famous linguist and the most influential translation theorist, belongs to the Prague School. His main contribution to translation studies is his notion of equivalence in difference. Based on his semiotic approach to language, Jakobson assigns the meaning of word to the sign, not the thing itself. He believes that any meaning of the linguistic sign is its future or alternative translation. (Jakobson, 2000). He tells three kinds of translation, namely, intralingual, interlingual and intersemiotic translation. 
As a distinguished Egyptian scholar working in England, Mona Baker talked about equivalence at different levels: word, grammar, text and pragmatics. Baker believes that a good translator cannot be reached until he or she has read the text and got the gist of the overall message. (Baker, 2000) One thing worth mentioning is that when comparing Eastern and Western languages, Baker often takes Chinese as a typical example and analyzes it, which has instructive significance to English-Chinese translation studies.

Eugene A. Nida, a renowned American scholar in the fields of translation theory and linguistics, is a key figure in equivalence theory. Talking about equivalence, we cannot overlook Nida's Dynamic/Functional Equivalence which is his most notable contribution to translation theory. It provides a theoretical framework for this paper. In his great work, Nida distinguished two different types of equivalence-formal equivalence and dynamic equivalence. Later in 1990s, Nida improved his functional equivalence theory by adding differences of culture and linguistics. In his revised theory, there existed two levels of equivalence: the minimal and maximal equivalence. The former one referred to the audiences in the TL text should be able to understand it to the degree that they can imagine how the SL readers must have understood it (Nida, 1993), while the later one was defined as readers in the TL should be able to understand it in basically the same style as the SL audience did. (Nida, 1993) Equivalence theory was quite popular in China's translation circle when it was introduced into China. But some translators and scholars began to suspect the rationality of functional equivalence since the end of the 20th century. In other word, can functional equivalence really be reached? Many people believe some untranslatability cannot be overcome.

\section{INTRODUCTION TO CHINESE-CHARACTERIZED TERMS}

Words, as the basic of a language, usually convey the unique background and history of a given country. For example, in English people say something is "as white as snow", but for a person who has never seen snow once during his life, he would be get puzzled when hearing this idiom. For them, they may have the expression like "white as egret feathers". (Nida, 2004). Also, as China gets stronger and more powerful in the international arena, more people from other countries hear the news from China, and they usually find some words with Chinese characteristics confusing. But the translation of the Chinese-characterized words are not easy because to some extends, some words are newly created instead of translated due to lack of precedent (Hatim, 1997). To lift the mysterious veil of the Chinese-characterized words, the most important thing is its definition.

\section{a. definition and characteristics of Chinese-characterized terms}

The saying "with Chinese characteristics" was first mentioned by Deng Xiaoping in "establishing the socialism with Chinese characteristics" when China began the reform and opening-up. This saying has existed for over three decades, yet there is no concrete definition for it. Yet, through collecting and analyzing these words with Chinese characteristics, the author of the paper finds a way to understand these words. That is, they are words unique to Chinese culture and history, and can be regarded as a cultural mark of the time-honored history and the glorious civilization of China (Zhao, 2011 ). For instance, "the culture revolution”, "people’s commune”, “the golden mean”, "jiaozi”, "three represents”, etc. And the all these words have several traits in common: they are characterized by their uniqueness or rarity and their rich implication of Chinese culture, moreover, most of them have no equivalents in English language or other languages.

\section{b. different types of Chinese-characterized terms}

All the words with Chinese characteristics can be classified into three categories, namely, Chinese-characterized words about culture and history, Chinese-characterized words about politics and economy, and Chinese-characterized words about daily life.

China is a country that boasts 5,000 years' history and fabulous culture. When we mention Chinese-characterized words about culture and history, they refer to the words that can be found nowhere but in the Chinese culture and history. For instance, "wen fang si bao" is translated as "The four treasure of the study", and they are further explained as "brush, ink stick, rice paper and ink stone". All these four things are indispensable for a man to write in ancient China, but in other countries, especially in the western countries, people do not know what they are. In addition, people would wonder about "rice paper". This kind of paper is made from parts of the rice plant, usually the stem, and is characterized by its delicate and lustrous quality and perfect ink absorption.

Take "hong men yan" as another example. It is rendered into "Hongmen banquet, a feast or meeting set up as a trap for the invited". And "qing ren yan li chu xi shi" is translated into "beauty is in the eye of a beholder". These two terms are related to historical figures in China's history and they are too numerous to mention one by one.

China's economy began to take off from the reform and opening-up, thus most of the political and economic words with Chinese characteristics are created in recent years. For example, tou fu zha gong cheng is translated into "a jerry-built project" which refers to buildings of bad quality. "Toufu" is a traditional food in China, which is soft and easy to break. So in Chinese people's daily life, when they talk about something delicate, they are inclined to describe it as easily-broken as toufu. However, for the foreigners out of China who know nothing about toufu they can still understand the expression "a jerry-built project". Other examples can be found as follows: the Great Leap Forward; the cultural revolution; Gang of four; four modernization; the shopping basket program; western development; etc. Since most of the Chinese-characterized words in the 18th national people's congress are about politics and economy, the author will elaborates on this type of Chinese-characterized terms in the following part.

If people talk about the words with Chinese characteristics relating to daily life, lots of this kind of words come to 
their mind immediately. Among them, the first ones come to people's mind are the words about Chinese food. While dealing with the translation of Chinese food, translators at first mainly resorted to two methods, namely, transliteration and literal translation. But a strange name cannot help westerns to better understand these words. Later, translators modified the translation by explaining the ways the foods are made when necessary. See the following examples of the first type: toufu; jiaozi, or dumplings with vegetables and meat fillings; kaoliang; shaomai. And terms of the second type can be found as: eight treasure congee; hot-hot-hot; four-joy meatballs braised with brown sauce; Royal Feast of Complete Manchu-Han Courses; diced chicken with chili and peanuts in hot sauce, invented by Gongbao in Qing Dynasty; Buddha jump over the wall; etc.

In addition, there are more new words with Chinese characteristics that have appeared in recent years. China Daily has had a collection of these terms in A Dictionary of New Chinese Phrases in English, and several examples are listed as follows: young people relying on their parents; (of a girl) find a sugar daddy; smuggled goods; scalped ticket; essential quality-oriented education and so on.

\section{Case Study---Translation of the Chinese-Characterized Terms in Hu JintaO’s RePORT ON THE 18Th NATIONAL PEOPLE'S CONGRESS}

\section{A. Chinese-characterized Words in Hu's Report on the 18th National People's Congress}

Due to the nature of the political documents, most of the words with Chinese characteristics in the 18th national report are about politics and economy. To be further divided, these words can be classified in several groups:

\begin{tabular}{|c|c|}
\hline $\begin{array}{l}\text { Words referring to guiding } \\
\text { ideology }\end{array}$ & $\begin{array}{l}\text { Mao Zedong Thought, Deng Xiaoping Theory, three represents, the Scientific Outlook on } \\
\text { Development, etc. }\end{array}$ \\
\hline Words related to socialism system & $\begin{array}{l}\text { socialist transformation, the basic system of socialism, the Party's basic line for the primary } \\
\text { stage of socialism, a socialist market economy, core socialist values, the superiority and } \\
\text { vitality of socialism, etc. }\end{array}$ \\
\hline $\begin{array}{l}\text { Words about economic } \\
\text { construction }\end{array}$ & a moderately prosperous society, socialist modernization, only development counts, etc. \\
\hline Words related to Taiwan & $\begin{array}{l}\text { the two sides of the Taiwan Straits, links of mail services, transport and trade, Economic } \\
\text { Cooperation Framework Agreement, the great renewal of the Chinese nation, the "one country, } \\
\text { two system" principle, etc. }\end{array}$ \\
\hline Words about politics & $\begin{array}{l}\text { the system of people's congresses, the system of multiparty cooperation and political } \\
\text { consultation under the leadership of the CPC, the system of regional ethnic autonomy, the system } \\
\text { of community-level self-governance, democratic centralism, etc. }\end{array}$ \\
\hline Other words & $\begin{array}{l}\text { the decision of the Seventeenth Party Congress, the new-democratic revolution, the Four } \\
\text { Cardinal Principles, issues relating to agriculture, rural areas and farmers, expand overseas } \\
\text { presence, activities to learn from paragons of virtue such as Lei Feng, traditional Chinese } \\
\text { medicine, the basic state policy of family planning, the three-step development strategy, etc. }\end{array}$ \\
\hline
\end{tabular}

\section{B. Two Points in Translation of Chinese-characterized Words from Functional Equivalence}

\section{a. Being Content-oriented}

The most important thing in translation is to keep the same content or meaning. Just as Nida and Taber described this point in their book: the translating process is composed of producing the natural equivalence both in meaning and style (Nida, 1993).

Chinese language has lots of styles, such as reduplication words and idioms composed by four Chinese characters, which are pleasant to the hearing, yet hard to be translated. When dealing with these terms, it is almost impossible for the translators to render them into English terms with rhythm as they used to be. But it does not matter if the purposes cannot be all reached. Above all, what counts is the meaning. See some words from Hu's report as follows: yang chang bi duan as play up strength and avoid weakness; guo tai min an as the country flourish and the people live in peace and harmony; ji si guang yi as draw on collective wisdom and absorb all useful ideas; xun si wu bi as bend the law for personal gain and engage in fraud; kai tuo jin qu as blaze new trails and forge ahead; qiu tong cun yi as seek common ground while shelving differences; lian jie feng gong as honestly perform one's official duties; etc.

All the Chinese terms above are composed of four Chinese characters, but the English version cannot be rendered into phrases at the same length. On this occasion, translators are supposed to keep in mind that content counts.

But from another aspect, these Chinese phrases have a trait in common: they can be parted from the middle, i.e. these expressions' meaning are the mixture of two shorter ones', say, "yang chang +bi duan" and "guo tai +min an". And it is obvious that the translation version also used "and" to indicate the connotation. From this point of view, the translators of the report have tried to be content-oriented and paid attention to the style as well.

Another instance is about the Chinese character "problem", which has occurred in the report for so many times.

Example 1. addressed the fundamental question of what kind of socialism and how we should build it

Example 2. China is faced with interwoven problems affecting its survival

Example 3. issues relating to agriculture, rural areas and farmers

Both of them are "problem", but the translation differs due to their varied meanings. And this surely proves the translation of Hu's report is content-oriented. 


\section{b. Being Receptor-oriented}

Besides the meaning, another significant factor in Nida's functional equivalence theory is the reaction of the target readers. Nida believed in a successful translation, the readers of the receptor language should basically have the same response as the original readers. Because of cultural differences and few knowledge of Chinese society, the western readers do not comprehend some terms with Chinese characteristics. To achieve the corresponding reaction of the receptor readers, the translators need to do lots of work. "Three representatives" has been quite familiar to Chinese, but to foreigners, they are still obscure. Thus they are furthered explained as: Three represents (the Party must always represent the development trend of China's most advanced culture, and represent the fundamental interests of the overwhelming majority of the Chinese people). "92 common acknowledgment" is translated as "the 1992 Consensus, in which the two sides of the Taiwan Straits all agreed on the one-China principle". This term often appears in the reports about Taiwan issue, yet few Chinese people know its meaning, let alone the foreign readers. "learn from Leifeng" activities is translated as learn from paragons of virtue such as Lei Feng. By adding "paragons of virtue such as Lei Feng", translators can help the target reader better understand this special activity in China.

\section{c. the achievement of functional equivalence in translation of Chinese-characterized words in Hu's report}

The National People's Congress is of great importance to China and Chinese people, and Hu Jintao's report on it tells people who pay close attention to China what has happened in China recently. In this way, the translation of the Hu's report serves as the exchange and communication between China and the world. Under the guidance of functional equivalence theory, the translating version has indeed made people around the world have a better understanding of China.

To begin with, it is about the accuracy of the meaning. From the genre point of view, the report is a governmental document or statement, to convey its exact meaning is paramount. In Nida's point of view, a successful translation should be the closest and natural equivalent". And the translation of Hu's report clearly expresses the meaning of the source report. At the same time, the English version has taken the receptor readers' response into consideration. Moreover the culture differences have been paid attention to. Both the last two are achieved through necessary explanation.

\section{d. the limitation of functional equivalence in translation of the Chinese-characterized terms}

The question of untranslatability has already been a hot topic for a long time. In English translation of the Chinese-characterized terms, some people doubt whether this theory can reach satisfactory effects. In Catford's view, there are linguistic untranslatability and cultural untranslatability (Catford, 1965). The linguistic one refers to the linguistic features while the cultural one occurs due to the cultural gap. From this point of view, it is easier to understand the limitation of functional equivalence in the Chinese-characterized terms translation. After all, every theory has its defects as well as its advantages.

\section{Three Major Translation Methods}

Chinese-specific terms have very deep cultural deposits, thus most of these words have underlying implications. And furthermore, Chinese and English differ in historical backgrounds, political conditions, social customs, thinking patterns and environmental surroundings, it is essential for translators to choose appropriate methods.

\section{a. Literal Translation}

Peter Newmark defined literal translation as: the SL grammatical constructions are changed to the closest TL equivalents but lexically, they are again translated (Newmark, 1988) That is to say, the precondition of literal translation is that there are almost equivalent expressions in the source language and target language. In this case, the translation fits the guidance of functional equivalence theory. Of course we can find some examples from Hu's report: socialism with Chinese characteristics, township and village enterprise, extensive economy, equality and mutual benefit, national welfare and the people's livelihood, etc. From these examples, it can be found that sometimes this kind of translation can even reach formal equivalence at the same time. But literal translation has its own disadvantage. Sometimes this method may mislead the translator and make the translation boring and that is what the translator should pay attention to. It is usually the case that the literal translation only helps name something, still it is unlikely for the target readers to understand its exact meaning and referent. On this occasion, translators often resort to annotation. That is, to attach more details to the literal translation. "three representatives" is a good example. Besides this, annotation is commonly used in explain some terms created by Chinese people or government. More can be seen in: three links, link of trade, travel and post; torch program, a plan to develop new and high technology; "eight honors and eight disgraces"; etc.

\section{b. free translation}

Free translation is always applied when it is difficult for translators to translate directly. In other words, in these cases, there are huge cultural gaps between the source language and the target language. As Nida mentioned, under this circumstance, if the translator still employs literal translation, the translated version may turn out to be obscure and hard to understand. (Nida, 1993) To some extent, free translation fits functional equivalence because it is hard to translate the form of the source language. And the author finds lots of free translation in Hu's report: the Party maintains close ties with the people; we must address ourselves to the problem of both material and spiritual civilization without any letup; development is the essential principle; the law of jungle; a younger, better-educated and more professional leadership; increasing revenue and saving on expenditures; etc. 
The author also discovers that "zou chu qu" is translated as "expand oversea presence" in Hu's report, but it was first translated into "going out" in the documents of the 16th national people's congress. Later, our translators and scholars replaced this expression with "going global". And now, China focuses more on creating her image of a great power and "zou chu qu" is rendered into "expand oversea presence". Thus the evolution of the translation of "zou chu qu" also shows that free translation emphasizes on the meaning. Also, free translation can be combined with annotation if necessary.

\section{c. transliteration}

The translation methods mentioned above cover most of ordinary translation, but when faced with the words and phrases with Chinese Characteristics, transliteration is a necessity. Transliteration means the words and expressions from the source language are translated according to their pronunciation.

Just as some people prefer to say "dao" instead of "mei yuan", people around the world say yuan, jiao, fen when they talk about Chinese money. And as China becomes more powerful, she also lays stress on strengthening its culture soft power. Chinese translators used to translate "jiao zi" into "dumplings with vegetable and meat fillings", and they may directly translate it into "jiaozi" without any further explanation in the future because maybe some years later all people in the world will know China's jiaozi. Yet, total transliteration without any explanation is not commonly-used. It is only used for the terms that have been included in English dictionaries like "Yin", "Yang" and "fengshui", etc (Zhao, 2011). And in most cases, translators should add further explanation. More examples can be seen in: kowtow, ama, ginseng, erhu, Chung-Yeung, Ching Ming, etc. These words are full of Chinese characteristics, and some even become current buzzword like Kongfu (Zhao, 2011).

\section{CONCLUSION}

Chinese-specific words are heavily culturally loaded. This paper probes into the translation of the words and phrases with Chinese characteristics. The author has quoted lots of examples. Take the 18th National People's Congress report English translation as classical example, the author has done research on the Chinese-characterized terms in Hu Jintao's report as a case study. The equivalence theory is one of the most influential translating theories. Among them, Nida's functional equivalence is what the author studies in this paper. From the development of functional equivalence, its contribution and disadvantage, the author shows a relatively detailed study on functional equivalence. And it has been found that Nida's functional equivalence theory can be the guiding principle for the translation of Chinese-characterized words, though it has limitation.

In regard to the translation of Chinese-characterized terms, it is impossible to provide an absolute and universal standard. Because there are too many factors to consider, it is hard for a translator to choose perfect approaches when translating. This paper also discusses three major translating methods from the perspective of functional equivalence. And because of the discrepancies between the two languages, it is unlikely to achieve completely equivalence in the translation of Chinese-characterized term. What translators can do is to preserve the images and the meanings to achieve equivalence of Chinese as much as possible.

\section{REFERENCES}

[1] Baker, Mona. (2000). In Other Words: A Coursebook on Translation. Beijing: Foreign Language Teaching and Research Press.

[2] Bassnett, Susan. (2004). Translation Studies. Shanghai: Shanghai Foreign Language Education Press.

[3] Catford, John. C. (1965). A Linguistic Theory of Translation: an Essay on Applied Linguistics: an Essay on Applied Linguistics. London: Oxford University Press.

[4] Hatim, Basil, and Ian Mason. (2001). Discourse and the Translator. Shanghai: Shanghai Foreign Language Education Press.

[5] Hatim, Basil, and Ian Mason. (1997). The Translator as Communicator. London: Rouledge.

[6] Jakobson, Roman. (2000). On Linguistic Aspects of Translation. London \&New York: Routledge.

[7] Munday, Jeremy. (2007). Introducing Translation Studies: Theories and Applications. Beijing: Commercial Press.

[8] Nida, Eugene. (2004). The Theory and Practice of Translation. Shanghai: Shanghai Foreign Language Education Press.

[9] Nida, Eugene A. (1993). Language, Culture, and Translating. Shanghai: Shanghai Foreign Language Education Press.

[10] Nida, Eugene A. (2004). Toward a Science of Translating. Shanghai: Shanghai Foreign Language Education Press.

[11] Peter, Newmark. (1988). A Textbook of Translation. Shanghai: Shanghai Foreign Language Education Press.

[12] Snell-Hornby Mary. (1995). Translation Studies, an Integrated Approach. Amsterdam and Philadelphia: John Benjamins Publishing Company.

[13] Zhao, Chongde. (2011). Practical Translation Studies and Exercise. Beijing: Commercial Press.

Xuedong Shi was born in Huhhot, Inner Mongolia, China in 1974. He received his MA degree in translation in Middlesex University, Britain, in 2004. He is currently a lecturer in the Foreign Language Department, Beijing Information Science University, Beijing, China. His academic research mainly focuses on translation and applied linguistics. 